"This is an Accepted Manuscript of an article published by Taylor \& Francis in [The Journal

of Ethnic and Migration Studies on $17^{\text {th }}$ April 2014, available online: http://wwww.tandfonline.com/[10.1080/1369183X.2014.907739].”

\title{
Transnational entrepreneurship amongst Vietnamese businesses in London
}

This paper draws on research with Vietnamese businesses in London which seeks to challenge some of the traditional views of transnational entrepreneurship. These have focused primarily on entrepreneurs embedded in both home and host countries and the need for regular travel between the two to manage the business. In contrast this study suggests that transnational entrepreneurship today is more fluid than previous studies have suggested and is often characterised by multi-polar (rather than bi-polar) links. Travel is also less relevant in the current age of 'super-connectivity'. The research explores how Vietnamese entrepreneurs in London draw on various forms of transnational capital to further the development of their business, and develops a framework to measure the degree and extent of the transnational embeddedness and dependency of the business. The results suggest that transnational entrepreneurship amongst ethnic minority entrepreneurs today is better viewed as a continuum rather than a set of discrete business types.

Keywords: UK Vietnamese Enterprise, Transnational Networks, Transnational Capital, Transnational Business Typologies, Ethnic Minority Entrepreneurship

\section{Introduction}

In the current era of globalisation an increasing number of ethnic minority entrepreneurs are part of transnational communities providing them with a diverse network of linkages that may span several nation states (Portes et al. 1999). These transnational networks can be seen as an enhanced form of social capital potentially providing ethnic minority entrepreneurs with access to a flow of resources, new market opportunities and business ideas (Bagwell 2008; Portes et al. 1999; Wong and Ng 2002). This 'diversity dividend', it is argued, can be used by otherwise disadvantaged ethnic minority entrepreneurs to gain a competitive advantage. Whereas previously economic success was seen to be dependent on the development of links with the mainstream, for these transnationally connected entrepreneurs success may depend instead on cultivating strong networks across national borders (Kariv et al. 2009; Portes et al. 1999). It is a strategy that has clearly benefited a number of businesses. McEwan et al. (2005), for example, describes how Chinese and South Asian entrepreneurs in Birmingham have drawn on their transnational links to source a huge range of food imports enabling them to establish successful supermarkets and ethnic food businesses in the city. However others argue that the advantage these diaspora links may offer are unlikely to outweigh the disadvantages of labour market conditions or deficiencies in human and financial forms of capital, which many ethnic minority enterprises face (Jones et al. 2010). Whilst a valid point, there is a danger here, that transnationalism is dismissed as being irrelevant to the vast majority of ethnic minority enterprises.

Part of the problem is that transnationalism can be interpreted in many different ways and it is not always clear, 'who to include and which type of practice(s) should be considered transnational' (Itzigsohn 1999:320). Definitions of transnationalism have traditionally focused on entrepreneurs who conduct business between the home and host country (Drori et 
al, 2009; Landolt 2001; Wimmer and Glick Schiller 2002), and have adopted the frequency of travel required to maintain the business as a key variable for classifying the extent or nature of transnationalism (Landolt et al. 1999; Rusinovic 2008). But transnationalism today is assuming new forms which are not necessarily dependent on moving back and forth between the sending and receiving country (Gowricharn 2009). Links may well be multipolar rather than bi-polar with actors relating to multiple localities (Amelina and Faist 2012; Levitt and Jaworsky 2007; Morgan 2001; Ong and Nonini, 1997). Furthermore advances in communication technology and the cheaper cost of communication now allows for faster and more frequent communication across the diaspora, enabling these distant links to be more easily sustained (Vertovec 2004). Face to face contact may still be required in the first instance to develop trust-based relationships (Chen and Wellman 2009). Once established, however, the physical movement of the entrepreneur becomes less relevant, since the management of the overseas arm of a business can now be maintained via email and Skype. Thus in this paper I argue that there is a need for a broader understanding of transnationalism that does not rely solely on the physical locations of the business and the extent of travel between them, but also considers the degree to which entrepreneurs access different forms of transnational support from the overseas diaspora.

To make this case the paper draws on recent research with the Vietnamese business community in London. This community has a widespread diaspora and a growing rate of entrepreneurship. It is one of the many new communities that are contributing to the superdiversity that now characterises the UK (Vertovec 2007). Whilst there have been a number of Canadian and US based studies of transnational enterprise (Kariv et al. 2009; Landolt 2001; Portes 2003) this is an area that, with a few exceptions (Jones et al. 2010; Kitching et al. 2009; McEwan et al. 2005), has been largely neglected in the UK, and this study seeks to help redress this imbalance. By exploring transnationalism amongst this ethnic minority business community the aim of this paper is to firstly explore how Vietnamese businesses in London draw on a variety of transnational forms of capital to further the development of their business, and secondly to use this data to test the appropriateness of traditional definitions of transnational entrepreneurship, and in particular a typology of transnational entrepreneurship developed by Landolt et al. (1999).

The paper commences with a review of relevant research on transnationalism amongst ethnic minority businesses and an outline of the conceptual framework. A brief overview of recent Vietnamese migration patterns and the research methodology follows. The analysis highlights key ways in which the transnational diaspora contributes to Vietnamese business development in the capital, and this leads to the development of a new framework for measuring transnational entrepreneurship better suited to current day practice. Finally the conclusions discuss the implications of the research for theories of transnationalism, policy and practice.

\section{Transnationalism Amongst Ethnic Minority Businesses}

Transnationalism was initially identified and defined by Basch et al. (1994:6) as, 'the process by which immigrants forge and sustain multi-stranded social relations that link together their societies of origin and settlement, and through which they create transnational social fields that cross national borders'. Various researchers have attempted to delimit transnationalism but marked differences have developed in views regarding what type of activities should be included and how extensive these should be in order to be considered transnational. At one end of the spectrum Portes et al. (1999) suggest that the term should be restricted to circumstances in which cross-border connections are extensive, regular and resilient. Travel 
at least twice a year for business purposes was adopted by their study as a key defining factor (Portes et al. 2002).

Based on this somewhat rigid definition Wong and Nga (2002:514) define a transnational enterprise as 'a business in the ethnic economy which entails separate operational components of the enterprise being located in different countries and the transmigration of the owners in order to operate it.' Such enterprises are unique in that they are socially embedded in both their home and host countries, potentially providing them with access to networks and resources in both environments. They differ from international enterprises since they tend to be reliant on the specific community and personal relationships within which the enterprise is embedded (Sequeira et al. 2009).

However others argue for a more flexible interpretation. Levitt (2001), for example suggests that transnationalism should include those who engage in occasional, informal transnational activities since taken together and over time these activities can have a significant impact. Similarly, Rusinovic (2008:433) talks in terms of transnational activities and networks - which she defines as 'contacts or associates in the home country which are of importance for the business of immigrant entrepreneurs'.

Of key importance in transnationalism is the enhanced social capital that transnationally connected ethnic minority enterprises are thought to benefit from, enabling them to leverage resources that might not otherwise be available. The concept of social capital as put forward by Bourdieu (1973) has been widely used to explain ethnic minority entrepreneurship (Coleman 1988; Nee and Sanders 2001). Viewed as the sum of resources (social, financial and cultural/human) that an individual is able to draw on, social capital is embedded in an individual's social networks (Bourdieu 1986). Transnational enterprises, being embedded in dual settings, potentially have access to an extended range of social capital. This can provide access to various transnational forms of capital, including economic capital (money to invest, and or/travel regularly), cultural/human capital (bilingualism, knowledge of overseas markets, international management experience) and social capital (such as contacts, relatives or family in the country of origin whom one can trust and/or do business with) (Rusinovic 2008).

Several studies have illustrated how this operates in practice. Ip (2007) outlines how Chinese migrants in Australia resorted to home ties to build their own business, borrowing money or developing and making use of transnational networks with China to broker deals, and arrange imports. Miera (2008) describes the thriving cross-border trade in products and services operated by transnational Polish entrepreneurs between Poland and Germany. Whilst in the UK Jones et al. (2010) note that UK Somali entrepreneurs routinely draw upon transnational links to access finance, labour and commercially useful information. Transnational networks have also been shown to provide access to new markets and increased sales (Kariv et al. 2009), and by facilitating the international movement of people, money and ideas between firms and across geographies, they encourage 'knowledge transfer' and contribute to business innovation (Coe and Bunnell 2001).

Recognising that transnational entrepreneurship comes in a variety of different shapes and sizes, Landolt et al. (1999) developed a typology based on a study of transnational business ventures found within the El Salvadoran immigrant communities of Los Angeles and Washington DC. The typology is based on identifying whether the key production inputs to an enterprise (i.e. the source of capital, labour, maintenance and expansion inputs and consumer markets are local (based in the host country) or transnational. Using these criteria ventures are classified as circuit, cultural, ethnic, return migrant, or elite. Circuit enterprises are the archetypical transnational business venture in which there is a flow of resources across borders. Start-up capital, labour, maintenance and expansion inputs are typically transnational and customers are both in the home and host country. Owners of circuit enterprises spend extensive amounts of time managing various aspects of the business from 
both countries. Cultural enterprises depend on migrants desire to consume traditional culturally specific goods such as music, newspapers and other media from home. Ethnic enterprises include a mix of small business ventures located in immigrant neighbourhoods and catering to a broadly ethnic clientele. Return migrant enterprises are the business ventures of migrants who have lived abroad and return to the home country. Finally elite expansion enterprises are those based in the home country that expand to serve the migrant community in the host country. This typology is summarised in Table 1 . Recently this framework was used with a study of 1,202 businesses from Latino immigrant groups (Colombians, Dominicans, and Salvadorans) located in several large cities in the US, and the typology was largely endorsed (Sequeira et al. 2009). However the dataset used was from 1999 and it is not clear if similar findings might be obtained with more recent data. Furthermore it has not been validated in contexts outside America, and it seems doubtful that every transnational enterprise can be neatly classified as being one of the five distinct types that Landolt et al's (1999) typology suggests.

More recently a study of transnational enterprises in the Netherlands developed an alternative typology based on the extent to which transnational activities were the main business activity or just an adjunct to other business activities, and whether travel to the home country for business purposes was required (Rusinvoic 2008). Based on these differences businesses were classed as having limited, moderate, or substantial transnational involvement. Whilst this acknowledges the different degrees of transnationalism it does not look at how transnational forms of capital contribute to the different production inputs to the business. Furthermore both Landolt et al's (1999) and Rusinovic's (2008) models place too much emphasis on the need for travel to maintain the business and tend to ignore links between countries other than the home and host country.

Table 1. Typology of transnational enterprises classified according to four dimensions of production process

\begin{tabular}{|l|l|l|l|l|}
\hline $\begin{array}{l}\text { Type of } \\
\text { enterprise }\end{array}$ & Start-up capital & Labour & $\begin{array}{l}\text { Maintenance } \\
\text { and expansion } \\
\text { inputs }\end{array}$ & Consumption \\
\hline Circuit & transnational & Transnational & Transnational & $\begin{array}{l}\text { Host and home } \\
\text { country }\end{array}$ \\
\hline Cultural & Host country & Host country & $\begin{array}{l}\text { Transnational } \\
\text { and host country }\end{array}$ & Host country \\
\hline Ethnic & Host country & Host country & $\begin{array}{l}\text { Host country } \\
\text { and } \\
\text { transnational }\end{array}$ & Host country \\
\hline Return Migrant & Transnational & Host country & Transnational & Host country \\
\hline Elite Expansion & Transnational & Transnational & Transnational & Host country \\
\hline
\end{tabular}

Summarised from Landolt et al. (1999) and Sequeira et al. (2009)

\section{Conceptual Framework}

The conceptual framework developed for this study follows Levitt (2001) and Rusinovic (2008) in adopting a fairly broad definition of transnationalism to take account of businesses involved in a variety of transnational activities which may be extensive, or just occasional but still important to the business. However transnational activity is not seen as being conducted 
solely between the host and home country, but could involve any country within the diaspora. The business may be able draw on transnational inputs to the business or access markets from, or via, contacts in one or many of these different 'nodes'. I suggest that the geographical extent of transnational activity can be defined in terms of the number of diaspora nodes where the business has a presence.

In identifying variables which could be used to measure transnational entrepreneurship the conceptual framework draws on elements of Landolt et al's (1999) model since although their transnational business types seem somewhat rigid, their framework does provide a useful means of isolating the transnational aspects of the key production and consumption processes involved in the business. However whilst this identifies tangible inputs to the business and consumption markets, it takes little account of the intangible inputs that are also important to business development and which may be sourced transnationally. In particular the role of the diaspora in providing advice, and contributing ideas for new products, services, and practices which support innovation in the business. Thus the conceptual framework developed for this study considers there to be five business processes which are important to the operation of the business and which may be supported or available transnationally or locally or both. These are the four identified by Landolt et al. (1999) (i.e. capital/finance required for start-up and expansion, labour required to staff the business, supplies/maintenance inputs, and consumption markets), as well as the intangible inputs advice and ideas. This study defines the degree of transnational embeddedness in terms of the number of businesses processes which involve transnational inputs or activity. It is suggested that businesses will show different degrees of transnational embededdness which could be extensive, moderate, limited, or none at all.

\section{The UK Vietnamese and its Diaspora}

The first major wave of recent Vietnamese migration occurred in the late 1970s after the fall of Saigon at the end of the Vietnam war. A further group left three years later as a result of the war between Vietnam and China in 1978-9 and worsening social and economic conditions (Refugee Action 2003). Many escaped in over-crowed small boats, and the plight of these 'boat people' became the subject of debate amongst the international community regarding which nations would provide them with refuge. They were eventually dispersed across several western nations - a policy which has resulted in many having extended family members across a number of different countries within the diaspora (Dorais 2001).

Whilst a large part of the Vietnamese diaspora consists of refugees it also includes others who left Vietnam for different reasons. From the 1980s on international family reunification programmes enabled a growing number of residents from Vietnam to legally join close relatives already living abroad. A further group of Vietnamese were sent to study in Eastern Europe and Russia in the 1980s as a result of bilateral treaties signed between these countries and the Socialist Republic of Vietnam. Others went to East Germany as contract workers and then settled there (Hüwelmeier 2011).

The exact number of Vietnamese who have left their country is difficult to assess, but as of 2005, the diaspora was estimated to be at least three million (Sidel 2007). Over half of these now live in the United States, but the rest are dispersed over sixty different countries with particularly large concentrations in France, Australia, Canada, and Thailand (Dorais 2001; Tran Trang Dan 1997 cited in Hardy 2004). The ease of travel and the opening up of some boarders has also allowed for onward migration. For example as a result of the expansion of the European Union, Vietnamese from Poland and the Czech Republic are now settling in the UK. 
An estimated 24,000 Vietnamese refugees arrived in the UK in the late 1970s during the first two waves of migration (IOM 2006). This was followed over the next 10 to 15 years by those allowed to settle as 'family-reunion' cases. However over the last decade or so a growing number of undocumented migrants are known to have entered the country and by 2006 community organisations estimated that there were around 55,000 people from Vietnam living in England and Wales of whom 20,000 were undocumented migrants (Sims 2007). Around 30 - 35,000 of all the Vietnamese in the UK are thought to be living in London (ibid).

The initial Vietnamese refugees suffered high levels of unemployment during their first few years of resettlement in the UK (Duke and Marshall 1997). From the mid 1990s, however, as they became more settled, a growing number began to establish small businesses - initially to service the local Vietnamese community (Bagwell 2006). No accurate statistics exist for the size of the UK or London-based Vietnamese business community. However, a study conducted in 2003 estimated that over 800 Vietnamese owned enterprises were operating in London at that time, in both local ethnic niche markets (particularly grocery shops and catering), but also increasingly in mainstream markets such as manicure services/nail salons (Bagwell et al. 2003).

This group of relatively recently established London based businesses therefore provided the opportunity to explore the key research questions of interest here, namely, how do UK Vietnamese businesses make use of different types of transnational capital? Secondly, what does this suggest about the appropriateness of existing definitions and typologies of transnational entrepreneurship?

\section{Methodology}

In the absence of a reliable database of Vietnamese businesses that could be drawn on for the sampling frame, a number of different methods were used to build up a picture of the Vietnamese business population in London. An earlier mapping study (Bagwell et al. 2003) provided a starting point and insight into the sectors in which Vietnamese businesses have traditionally been concentrated, and their geographical spread. Interviews with a wellestablished Vietnamese community organisation helped provide a more up to date overview. Two Vietnamese research assistants (one from the north and one from the south of Vietnam) were recruited to assist with collecting further intelligence. They also helped identify businesses willing to participate in the research, and translated where necessary. Amongst the older generation of Vietnamese in the UK there are still strong divisions between those who originated from the communist north, as opposed to those from the more capitalist orientated south of Vietnam, and employing a research assistant from each area assisted in securing access to businesses from each group. This approach enabled a targeted sampling strategy to be adopted (Watters and Biernacki 1989), designed to reflect the range of business types, their geographical spread, sectors and size. Since the generation of the owner manager has been found by other studies to influence the level of transnational activity in the business (Rusinovic 2008), care was taken to ensure that the sample included both first and second generation entrepreneurs. The first generation included both businesses run by the original group of refugees $(n=13)$, and more recent economic migrants who had arrived during the last 15 years and have been labelled 'first generation new arrivals' $(n=8)$. The second generation were those who had arrived in the UK before the age of $12(n=3)$. New business contacts were generated through chain referrals from the initial businesses interviewed (following Biernacki and Waldorf 1981). Approaching businesses through different channels in this way allows for a variety of networks to be drawn on (ibid). Whilst this can in no way claim to result in a statistically representative sample it does increase the likelihood of selecting a 
group of businesses that broadly reflects the total UK Vietnamese business population in London, and is a method that has been used by others for researching hidden populations (Jones et al. 2010; Ram et al. 2008). A total of 24 businesses agreed to be interviewed as a result of this approach. The focus of this study was UK based businesses and thus those that might be described by Landolt et al (1990) as return migrant or elite enterprises, and which had their headquarters in Vietnam, were not included. Table 2 summarises the key characteristics of the interviewees and their businesses.

Table 2 Owner manager and business characteristics

\begin{tabular}{|c|c|c|c|c|c|}
\hline \multirow[b]{2}{*}{ Business } & \multicolumn{2}{|c|}{ Business Characteristics } & \multicolumn{3}{|c|}{ Owner Manager Characteristics } \\
\hline & $\begin{array}{c}\text { Age of } \\
\text { business }\end{array}$ & Physical bases & $\begin{array}{c}\text { Sex of Owner } \\
\text { Manager }\end{array}$ & $\begin{array}{l}\text { Generation of } \\
\text { Owner Manager }\end{array}$ & $\begin{array}{c}\text { Highest } \\
\text { educational level } \\
\text { of owner } \\
\text { (location) }\end{array}$ \\
\hline Nail Supplier 1 & 14 & $U S+U K+V N$ & Male & $1 \mathrm{st}$ & Graduate (US) \\
\hline Travel Agent 1 & 3 & $\mathrm{UK}+\mathrm{VN}$ & Male & $1 \mathrm{st}$ & $\begin{array}{l}\text { Graduate (Vietnam } \\
\text { and France) }\end{array}$ \\
\hline Wholesaler & 11 & $\mathrm{UK}+\mathrm{VN}$ & Male & $1 \mathrm{st}$ & Graduate (UK) \\
\hline Website/advice & 2 & None - virtual & Male & $1^{\text {st }}$ new arrival & Graduate (UK) \\
\hline Restaurant 1 & 8 & UK & Female & $1^{\text {st }}$ & $\begin{array}{l}\text { Secondary } \\
\text { (Vietnam) }\end{array}$ \\
\hline Coffee Shop & 5 & UK & Male / Female & $1^{\text {st }}$ new arrival & $\begin{array}{l}\text { Graduate } \\
\text { (Vietnam) }\end{array}$ \\
\hline Nail Supplier 2 & 0.5 & UK & Male & $1^{\text {st }}$ new arrival & Graduate (UK) \\
\hline Nail Supplier 3 & 8 & UK & Male/Female & $1 \mathrm{st}$ & $\begin{array}{l}\text { Secondary } \\
(\text { Vietnam + UK) }\end{array}$ \\
\hline Nail Salon 1 & 10 & UK & Female & 2nd & $\begin{array}{l}\text { BTEC Business } \\
\text { Admin (UK) }\end{array}$ \\
\hline Nail Salon 2 & 16 & UK & Female & $1 \mathrm{st}$ & $\begin{array}{l}\text { Secondary } \\
\text { (Vietnam) }\end{array}$ \\
\hline Supermarket 1 & 0.5 & UK & Male & 1st new arrival & $\begin{array}{l}\text { Secondary (Czech } \\
\text { Republic) }\end{array}$ \\
\hline Travel Agent 2 & 8 & UK & Female & $1^{\text {st }}$ new arrival & Graduate (Poland) \\
\hline Video Rental & 14 & UK & Female & $1 \mathrm{st}$ & $\begin{array}{l}\text { Secondary } \\
\text { (Vietnam) }\end{array}$ \\
\hline Market Stall & 3 & UK & Female & $1^{\text {st }}$ new arrival & Graduate (US) \\
\hline Restaurant 2 & 25 & UK & Male & $1 \mathrm{st}$ & $\begin{array}{l}\text { Graduate } \\
\text { (Vietnam) }\end{array}$ \\
\hline Supermarket 2 & 15 & UK & Male / Female & $1 \mathrm{st}$ & $\begin{array}{ll}\text { Graduate } & (\mathrm{UK}) / \\
\text { Secondary } & \\
\text { (Vietnam) } & \\
\end{array}$ \\
\hline Supermarket 3 & 12 & UK & Male & $1 \mathrm{st}$ & $\begin{array}{l}\text { Secondary } \\
\text { (Vietnam) }\end{array}$ \\
\hline Accountant & 4 & UK & Female & $1^{\text {st }}$ new arrival & $\begin{array}{l}\text { Accountancy } \\
\text { Graduate (UK) }\end{array}$ \\
\hline Garage & 10 & UK & Male & $1 \mathrm{st}$ & Primary (Vietnam) \\
\hline Restaurant 3 & 3 & UK & Male & 2nd & Secondary (UK) \\
\hline Restaurant 4 & 3 & UK & Female & $1^{\text {st }}$ new arrival & Graduate (UK) \\
\hline Shoe Shop & 10 & UK & Male & $1 \mathrm{st}$ & $\begin{array}{l}\text { Secondary } \\
\text { (Vietnam) }\end{array}$ \\
\hline Travel Agent 3 & 5 & UK & Female & 2nd & Graduate (UK) \\
\hline Take Away & 13 & UK & Male & $1 \mathrm{st}$ & $\begin{array}{l}\text { Secondary } \\
\text { (Vietnam) }\end{array}$ \\
\hline
\end{tabular}

Graduate $=$ University graduate $\quad$ Secondary $=$ Secondary school $\quad$ Primary $=$ Primary school 
In-depth face to face interviews were held with the owner manager of each business in English $(n=18)$ and/or Vietnamese $(n=6)$ between October 2011 and September 2013. The interviews sought to gather data on basic firm level factors, the nature of any transnational activities, and the extent to which different forms of transnational capital were used to support the start-up and operation of the business. Businesses were questioned about the role played by the overseas diaspora in contributing both tangible inputs to the business i.e. finance (for start-up, maintenance, or expansion), labour, supplies, and consumption markets; as well intangible inputs i.e. business ideas and advice. The frequency of overseas travel required for business purposes, the number of nodes of the diaspora involved in the business, and the influence of the political, economic and structural constraints and opportunities in these areas was also discussed. Finally if the business was not involved in any transnational activity the reasons for this were explored. A broad checklist of open-ended questions was used to ensure that these key points were covered, but was also designed to prompt discussion of any additional related issues that might emerge. The interviews lasted between 45 minutes and 1.5 hours each and were taped and transcribed, and then analysed using NVivo software. An attributes table was produced to analyse the number and type of key inputs to the business, and the frequency of travel (See Table 3). The interview data was also coded and analysed using these key themes and other emergent themes identified using a grounded theory approach (Strauss and Corbin 1990).

\section{The Extent and Use of Transnational Inputs to the Business}

From table 2 it can be seen that just three of the businesses operated from sites in more than one country and thus met the classic definition of a transnational business (Portes et al. 1999; Wong and Nga 2002) This finding could be seen as endorsing the results of previous research which has suggested that transnationalism is the exception rather than the rule (Jones et al. 2010). However all but seven of the remaining 21 businesses made use of their transnational connections to support one or more aspects of the production process (see table 3).

These links provided access to a variety of transnational forms of capital. They enabled ten of the businesses to source products via the overseas diaspora which could not be found in the UK. The video store owner, for example, used her transnational contacts to help with the sourcing and importing of Vietnamese media products, including CDs, videos, DVDs, and karaoke systems and discs from the US, Vietnam and France. Since these countries had a much larger Vietnamese population than that of the UK they tended to produce a greater range of multi-media material targeted at the community. Six businesses had relied on family overseas to help finance the start-up or expansion of their business, whilst five had used these links as a source of labour, albeit often informal. Contacts overseas provided introductions to new customers and were an important source of new consumption markets for four businesses. Nail supplier 3, for example, had a customer base which extended across eight different countries as a result of the business's network of linkages within the diaspora.

For just over half of all the businesses $(n=13)$ their transnational contacts were also a fertile source of inspiration for new business ideas, products and processes. This might not result in the flow of tangible resources across borders, but nevertheless was clearly providing the businesses with an important source of intangible transnational capital. One of the nail salon owners explained how she was able to keep up with the latest fashions for nail designs emerging from the US by visiting friends and relatives with nail salons there. 
Table 3. Extent of transnational inputs and activities

\begin{tabular}{|c|c|c|c|c|c|c|c|c|c|c|}
\hline \multirow{2}{*}{ Business } & \multicolumn{6}{|c|}{ Transnational Inputs and Markets } & \multirow{2}{*}{ Physical bases } & \multirow{2}{*}{$\begin{array}{c}\text { No. diaspora } \\
\text { nodes } \\
\text { involved }\end{array}$} & \multirow{2}{*}{$\begin{array}{c}\text { No. overseas } \\
\text { business trips } \\
\text { p.a. }\end{array}$} & \multirow{2}{*}{$\begin{array}{c}\text { Degree of transnational } \\
\text { embeddedness }\end{array}$} \\
\hline & $\begin{array}{l}\text { Ideas \& } \\
\text { advice }\end{array}$ & Finance & Labour & Supplies & $\begin{array}{l}\text { Consumpt'n } \\
\text { markets }\end{array}$ & $\begin{array}{l}\text { No. transnat' } \\
\text { inputs }\end{array}$ & & & & \\
\hline Nail Supplier 1 & $\mathrm{~T}$ & $\mathrm{~T}$ & Both & Both & Both & 5 & US+UK+ VN & 8 & $<1$ & Extensive \\
\hline Travel Agent 1 & Both & $\mathrm{T}$ & $\mathrm{T}$ & $\mathrm{T}$ & Both & 5 & $\mathrm{UK}+\mathrm{VN}$ & 2 & 3 & Extensive \\
\hline Wholesaler & Both & $\mathrm{L}$ & Both & $\mathrm{T}$ & Both & 5 & $\mathrm{UK}+\mathrm{VN}$ & $5+$ & 3 & Extensive \\
\hline Website/advice & Both & $\mathrm{L}$ & Both & Both & Both & 4 & None & 1 & 1 & Moderate \\
\hline Restaurant 1 & Both & Both & Both & $\mathrm{L}$ & $\mathrm{L}$ & 3 & UK & 3 & 1 & Moderate \\
\hline Coffee Shop & $\mathrm{T}$ & $\mathrm{L}$ & $\mathrm{L}$ & $\mathrm{T}$ & Both & 3 & UK & 1 & 1 & Moderate \\
\hline Nail Supplier 2 & $\mathrm{~T}$ & $T$ & $\mathrm{~L}$ & Both & $\mathrm{L}$ & 3 & UK & 1 & 1 & Moderate \\
\hline Nail Supplier 3 & $\mathrm{~T}$ & Both & $\mathrm{L}$ & Both & Both & 4 & UK & 5 & 1 & Moderate \\
\hline Nail Salon 1 & Both & $\mathrm{T}$ & Both & Both & $\mathrm{L}$ & 4 & UK & 1 & 1 & Moderate \\
\hline Nail Salon 2 & Both & $\mathrm{T}$ & $\mathrm{L}$ & $\mathrm{T}$ & $\mathrm{L}$ & 3 & UK & 1 & $N / A$ & Moderate \\
\hline Supermarket 1 & $\mathrm{~L}$ & $\mathrm{~T}$ & Both & Both & $\mathrm{L}$ & 3 & UK & 2 & N/A & Moderate \\
\hline Travel Agent 2 & $\mathrm{~T}$ & $\mathrm{~L}$ & $\mathrm{~L}$ & $\mathrm{~L}$ & Both & 2 & UK & 3 & 1 & Limited \\
\hline Video Rental & $\mathrm{T}$ & $\mathrm{L}$ & $\mathrm{L}$ & $\mathrm{T}$ & $\mathrm{L}$ & 2 & UK & 2 & 3 & Limited \\
\hline Market Stall & $\mathrm{T}$ & $\mathrm{L}$ & $\mathrm{L}$ & $\mathrm{L}$ & $\mathrm{L}$ & 1 & UK & 1 & 1 & Limited \\
\hline Restaurant 2 & $\mathrm{~L}$ & $\mathrm{~L}$ & Both & $\mathrm{L}$ & $\mathrm{L}$ & 1 & UK & 1 & 0 & Limited \\
\hline Supermarket 2 & $\mathrm{~L}$ & $\mathrm{~L}$ & $\mathrm{~L}$ & Both & $\mathrm{L}$ & 1 & UK & 1 & $<1$ & Limited \\
\hline Supermarket 3 & $\mathrm{~L}$ & $\mathrm{~L}$ & $\mathrm{~L}$ & Both & $\mathrm{L}$ & 1 & UK & 3 & 1 & Limited \\
\hline Accountant & $\mathrm{L}$ & $\mathrm{L}$ & $\mathrm{L}$ & $\mathrm{L}$ & $\mathrm{L}$ & 0 & UK & 0 & $<1$ & None \\
\hline Garage & $\mathrm{L}$ & $\mathrm{L}$ & $\mathrm{L}$ & $\mathrm{L}$ & $\mathrm{L}$ & 0 & UK & 0 & 0.2 & None \\
\hline Restaurant 3 & $\mathrm{~L}$ & $\mathrm{~L}$ & $\mathrm{~L}$ & $\mathrm{~L}$ & $\mathrm{~L}$ & 0 & UK & 0 & N/A & None \\
\hline Restaurant 4 & $\mathrm{~L}$ & $\mathrm{~L}$ & $\mathrm{~L}$ & $\mathrm{~L}$ & $\mathrm{~L}$ & 0 & UK & 0 & $\mathrm{~N} / \mathrm{A}$ & None \\
\hline Shoe Shop & $\mathrm{L}$ & $\mathrm{L}$ & $\mathrm{L}$ & $\mathrm{L}$ & $\mathrm{L}$ & 0 & UK & 0 & 0 & None \\
\hline Travel Agent 3 & $\mathrm{~L}$ & $\mathrm{~L}$ & $\mathrm{~L}$ & $L$ & $\mathrm{~L}$ & 0 & UK & 0 & $<1$ & None \\
\hline Take Away & $\mathrm{L}$ & $\mathrm{L}$ & $\mathrm{L}$ & $\mathrm{L}$ & $\mathrm{L}$ & 0 & UK & 0 & $<1$ & None \\
\hline
\end{tabular}


Three years ago I went to Orlando Florida to learn the techniques and how to run the business. We copied things there and brought them back here. ..because we wanted to bring the latest products to the UK.... So we brought those products and new styles for nails back here.....

(Nail salon 2) ${ }^{1}$

Such transnational inputs could thus provide the business with a competitive advantage providing access to cheap labour, new products, and new markets.

For the most transnationally active with a business base and family members overseas, a distinct collective family approach to the management of transnational forms of capital frequently operated in which resources and family members were moved to the most advantageous location for the business. Nail supplier 1 , for example, had initially migrated to the US before joining his brothers in the UK. Other family members had remained in Vietnam enabling different aspects of the business to be run in all three countries as follows:

In my family seven brothers and sisters; two in Seattle one in Canada. Four brothers work in the business. I run the retail outlet here in London. Another brother in London runs the wholesale warehouse, one brother running table factory in Vietnam - Saigon - he sells to everyone. Another brother recently set up another table factory in Vietnam - just to supply us to ensure that we don't have to wait for supplies and the fourth brother is a supplier in Birmingham.

(Nail supplier 1)

For some other businesses, however, the use of transnational inputs was a necessity for business survival rather than a preferred strategy, and indeed sometimes carried an element of risk. One of the restaurants explained how the hiring of Vietnamese chefs in the UK has become so problematic that they were sometimes forced to rely on undocumented transnational labour which could result in heavy fines if discovered by the tax authorities.

The hiring of transnational labour might also be a family obligation, in response to strong cultural values which emphasise the need to support the wider family, and which past research has found to be particularly common amongst Vietnamese family enterprises, and not always in the best interests of the business (Bagwell 2008). One of the restaurants interviewed was employing her niece whilst she studied in the UK, and others reported that they were often asked by overseas family members to provide employment for various members of the extended family.

Thus even micro enterprises which do not have a base overseas may be involved in a significant range of transnational activity making use of tangible and/or intangible transnational forms of capital, out of necessity, to meet family obligations, or to provide the business with a competitive advantage.

\section{Nodes of Transnational Inputs and Influence}

The circumstances of their migration and the lack of support for private enterprise in Vietnam under the former communist regime has meant that transnational business links with the homeland have only become feasible in recent years. Since the late 1990s the Vietnamese economy has undergone radical reform and relations with the west are now encouraged (Thai and Ngoc 2010). However this is only now beginning to impact on transnational business opportunities and as a result London-based Vietnamese businesses have tended to rely on support from members of the diaspora in a many different countries, not just the home

\footnotetext{
${ }^{1}$ This quote has been edited by the author to facilitate clarity
} 
country. From Table 3 it can be seen that some of those interviewed had business links with as many as five or more different nodes of the diaspora. Typical scenarios included.

My brother in Germany helped me with a loan for this restaurant (Restaurant 1).

I borrowed money (to buy the business) from family in Vietnam and Czech Republic (Supermarket 1)

Friends all over the world give information on products, check goods before shipping (Video rental business)

Access to different nodes of the diaspora frequently provided a wider choice of sources from which to obtain products. Supermarket 1, for example, explained how his sister in the Czech Republic, who also owned a supermarket, helped him source, buy, and check products, whilst friends delivered them to the UK. This link enabled him to obtain food products that could not be imported legally from Vietnam or Thailand, but which were allowed in if they entered the country from the Czech Republic. By circumventing the restrictions on direct imports from Vietnam in this way the business was able to stock some specialist Vietnamese foods that could not be found elsewhere in London - thus providing the business with a profitable niche market.

Rather than viewing transnational entrepreneurship as characterised by the flow of resources between home and host countries, as described by much of the transnational literature, the picture here is of a network of linkages across multiple nodes of the diaspora. These provide a range of potential transnational inputs allowing UK based businesses with the necessary contacts and appropriate enterprises to tap into the most advantageous node.

\section{From transnational business typologies to a continuum of transnational entrepreneurship}

Analysis of the extent to which the businesses could usefully be classified using Landolt et al's (1999) framework suggested that the typology did not hold very well with this group of businesses. In particular the sample here included a number of transnational businesses catering to the mainstream as opposed to local co-ethnic markets. Nail salons and many of the Vietnamese restaurants being the key examples here. Such business types are not covered by Landolt et al's (1999) typology. Furthermore the use of transnational start-up capital and labour was not confined to the transnational businesses with a base overseas (Landolt et al's circuit businesses - see table 1), but was evident in many of the other types of businesses interviewed here. Indeed the picture that emerges is, as noted above, of quite sophisticated family strategies for moving capital across the diaspora with even some of the smallest local ethnic businesses being just as likely to have benefited from an injection of transnational financial capital as those with an actual physical base overseas. Whilst the UK Vietnamese business community's circumstances are very different to the El Salvadoran sample studied by Landolt et al in the US in the late 1990s, it is clear that the typology is not directly transferable to the context of current day ethnic minority entrepreneurship in the UK. Landolt et al.'s (1999) definition of ethnic businesses tends to draw on notions of the ethnic enclave economy - a concept that is less relevant to the Vietnamese and many other ethnic minority communities in London today.

Analysis of the interview data and the extent of transnational inputs to the business led to the conclusion that most businesses could not easily be classified as distinct business types. The situation was far more fluid. It was clear however, that differences did exist in the degree to which businesses relied on transnational inputs to the business. Some were clearly 
not involved in any transnational activity, whilst at the other end of the spectrum were businesses which were deeply embedded in two or more countries with premises and staff in the UK and overseas. Most businesses fell somewhere between these extremes. They had varying degrees of transnational embeddedness as measured by the number of business processes which involved transnational forms of capital or activity (See table 3). For illustrative purposes these businesses are categorised as having extensive, moderate, limited, or no level of transnational embeddedness, depending on the number of business processes which involved transnational inputs or activity, and a brief description of each follows. These are not rigid categories, but have been created as a means of highlighting the different degrees of transnational embeddedness and dependency that were found in the businesses interviewed.

\section{Group A: Businesses with an extensive level of transnational embeddedness}

Those with the most extensive level of transnational embeddedness and dependency met the classic definition of a transnational business in that they had an overseas base. These three businesses, which included a nail supplier, travel agent and wholesaler, were able to draw on the greatest level of transnational capital. All five of their business processes involved transnational inputs or activity (see Table 3). Analysis of the interview data suggested that their greater degree of transnational activity could be explained by the history of family migration, and their access to extensive levels of transnational and human capital. Travel agent 1, for example, had migrated to the UK after studying in France. He gained several years' management experience in another Vietnamese business before deciding to set up on his own. His brother and sister had remained in Vietnam, where they now ran a branch of the business specialising in local tours and travel arrangements for the growing number of Vietnamese wanting to visit the UK. Similarly nail supplier 1 had family members and business experience in the US and Vietnam, with the result that the business was embedded in the three key locations of importance for the industry. New ideas and products could be sourced from the US, the table manufacturing side of the business was based in Vietnam to take advantage of the cheaper cost of labour and supplies there, and a base in London provided easy access to the growing number of nail salons in the UK and Europe.

In line with the findings of other studies (Bagwell 2008; Wang and Ng, 2002; Landolt 2001), the presence of family members, friends and contacts within the transnational diaspora was found to be particularly important for the maintenance of the overseas sites. They also reduced the need for the business owner to travel back and forth so frequently. Thus Nail Supplier 1 had only travelled to Vietnam once in the last 10 years as his two brothers based in Vietnam managed the overseas operations of the business. Family members such as these also provided the necessary language, cultural knowledge, and contacts, and could be trusted to manage different aspects of the business oversees which might be difficult without a local presence. Nail supplier 1 explained,

It's hard managing a factory in Vietnam - brothers need to be there to oversee quality control and to avoid corruption (Nail supplier 1)

A notable exception, however, was the wholesaler who employed a professional team of trusted staff, rather than family members, to run the overseas arm of the business in Vietnam. Although all three of these business owners were well educated and widely travelled, the owner of this wholesale business had had significant management experience with major investment banks before starting his business. Migrants with higher levels of human capital such as this have been found to rely less on ethnic social capital in establishing their firms 
than those who do not have the same level of education, skills and experience (Marger 2001; Nee and Saunders, 2001). In his case the owner's considerable human and cultural capital meant that he was able to draw on mainstream contacts as well as co-ethnic social capital and networks to support the development of the business.

\section{Group B: Businesses with a moderate level of transnational embeddedness}

This formed the largest group of businesses $(n=8)$. It included the website advice portal, one restaurant, the coffee shop, two nail suppliers, two nail salons, and a supermarket. Three or four of these enterprises business processes involved transnational inputs or activity. Finance was typically provided by family members overseas. Nail suppliers and nail salons tended to get financial support from family and friends in Vietnam or the US for example. The supermarket had received a loan from family members in Vietnam and the Czech Republic to start the business. Being based solely in the UK, labour for most businesses was usually found locally from amongst the local Vietnamese community, although nail salons and restaurants might also employ some transnational economic migrants from Vietnam as the cash based nature of these businesses lent itself to the employment of casual or informal transnational labour. The website business also relied on friends in Vietnam to translate newspaper articles, legal and social welfare advice, and UK websites into Vietnamese, Supplies were sometimes sourced transnationally, but the increasing presence of Vietnamese wholesalers in the UK meant that businesses also had the option of purchasing products locally. Consumption markets were also predominantly local, with the exception of the coffee shop and nail supplier 3 who sold products online, and as a result had customers in a growing range of overseas countries. All the businesses made use of the overseas diaspora to provide advice and inspiration for new business ideas and travelled overseas for business purposes at least once a year.

Thus whilst not so embedded in two or more countries as those with an overseas base these businesses nevertheless had a web of transnational contacts which allowed for a range of tangible and intangible support to be sourced from overseas. This was frequently combined with locally sourced resources and inspiration, thus providing an extended source of social, cultural and financial capital. For example one nail salon owner sourced new ideas regarding nail designs and products from the US, but adopted retail strategies observed in the UK - in this case operating a loyalty card scheme - thus illustrating how 'glocalised' networks (Chen and Tan 2009) can operate to provide a competitive advantage.

\section{Group C: Businesses with a limited level of transnational embeddedness}

This group of six businesses included those who had transnational inputs in just one or two of their business processes. It included one travel agent, the video rental business, the BanhMi ${ }^{2}$ market stall holder, one restaurant, and two of the supermarkets. These businesses tended to be similar to the ethnic businesses described by Landolt et al. (1999), as they were mostly selling traditional Vietnamese products, and with the exception of the restaurant and the BanhMi market stall holder, were largely serving the local Vietnamese market. The travel agent was the only business in this group to have transnational as well as local consumption markets, with customers from the Vietnamese community in the UK, Vietnam and Poland. All of the businesses had obtained finance locally, and all but one (the restaurant) relied on local labour. The two supermarkets imported some, but not all of their supplies, transnationally, whilst the video rental business, in contrast was heavily reliant on the

\footnotetext{
${ }^{2}$ BanhMi is a French baguette filled with fresh savoury fillings
} 
transnational diaspora for locating and importing new products. Finance for these businesses was generally obtained locally. Ideas and advice were obtained locally by three of the businesses, but the remaining three also drew inspiration from the overseas diaspora. The BanhMi market stall holder, for example, had developed the business idea during the course of travels undertaken whilst working and studying overseas, and during trips home to family in Vietnam. Travelling for business purposes was rare (with the exception of the video rental business) for this group and was generally linked to trips home to see family.

Thus the transnational activity of these businesses and their use of transnational forms of capital was relatively limited. In contrast to the businesses in the previous two groups these businesses were more locally orientated.

\section{Group D: Businesses with no transnational involvement}

Seven of the businesses had a totally local orientation and did not appear to make use of any transnational links they might have to assist with the start-up or operation of their business. These included three supplying a service to the local Vietnamese community (the accountant, garage, and travel agent) and four who were predominantly servicing the mainstream (two restaurants, the takeaway, and the shoe shop). It was notable that the owners of these businesses made fewer trips abroad than the more transnationally active businesses. For many the lack of financial capital restricted the extent to which they could travel and gather information about potential new products or develop links with suppliers. The owner of the takeaway, for example, bemoaned the fact that he had not been able to afford the trip home to Vietnam for several years. Struggling to keep the business afloat in the presence of increasing competition and rising premises costs, a trip back home was considered an unaffordable luxury. The shoe shop owner had links with potential Vietnamese suppliers in Vietnam and China, but his business was not in a position to import directly from them, as to do so required the purchase of much larger quantities than he could finance at present. In the absence of the necessary level of (local or transnational) financial capital he was forced to buy his stock from UK based wholesalers. Thus, although these businesses often had access to transnational social capital in the form of strong family ties overseas, the nature of their business, the presence of wholesalers locally, and their lack of access to local or transnational financial and human capital acted as a constraint on the type of business that could be established and the scope for expansion.

\section{Conclusions}

The research leads to a number of conclusions regarding the nature of small scale transnational entrepreneurship amongst the UK Vietnamese community which may be relevant to other ethnic minority groups, although further research is needed to ascertain this.

Firstly UK Vietnamese businesses vary considerably in the extent to which they engage in transnational activities and range from those with business operations in several countries to small locally based enterprises which rely on the transnational diaspora for tangible inputs such as finance, labour, supplies, and markets, or intangible support including new business ideas and advice, and frequently a combination of these. The nature and extent of transnational business activity depends on the history of migration which determines the geographical dispersion of transnational links, the nature of the business, the availability of transnational forms of capital - both tangible and intangible, as well as a conducive structural 
and political environment, personal circumstances, and the necessary skills and experience to develop and manage a successful business. The most transnationally embedded businesses in this study tended to have higher levels of human and/or financial capital (local, transnational or both) as well as access to transnational social capital (in the form of family and friends in the diaspora) able to assist with overseas operations. In contrast the least transnationally embedded businesses tended to have lower levels of local and transnational forms of capital or were operating in sectors in which transnational inputs to the business were unlikely to offer a particular competitive advantage.

It could be argued that those businesses which are less transnationally embedded and do not have an overseas base are not really transnational enterprises in the strictest sense. Failing to take account of the role of the transnational diaspora in supporting many of these businesses through the provision of different transnational forms of capital, however, would risk missing an important influence on the business - and in many cases a vital source of innovation and on-going business support. Transnationalism is thus perhaps better viewed as a continuum ranging from those with extensive cross border connections who are fully embedded in two or more countries, to those for whom such links may be less active but are still important for the business to varying degrees. This views transnational business activity as a far more fluid process than has traditionally been thought of in the past.

To assist in understanding the level of a business's transnational embeddedness this study has developed a framework to measure both the degree and the extent of transnational inputs and activities in the business. It is suggested that the degree of transnational embeddedness can be measured by looking at the five key business processes. These include tangible inputs: capital/finance required for start-up and expansion, labour required to staff the business, supplies/maintenance inputs, and consumption markets, and one intangible input: advice and ideas. Businesses will show different degrees of transnational embeddedness depending on the number of these inputs and activities which are transnational or not. This study has also shown that models of transnationalism should not be focused solely on links between home and host countries, but should consider the multiple nodes of influence. Identifying the number of countries or nodes of the diaspora which are involved in the business provides a measure of the geographical spread or extent of the business's transnational activity. Most importantly it is suggested that this framework should be used to assess the degree and extent of transnational embeddedness rather than as a means, as the Landolt et al. (1999) framework suggests, of categorising businesses as distinct types of transnational enterprises.

This interpretation of transnational entrepreneurship places less emphasis on the frequency of overseas travel than earlier studies (Portes et al. 2002). Whilst the most transnationally embedded businesses in this study did undertake slightly more overseas business trips than those with lessor degrees of transnational embeddedness there were several exceptions to this general trend. With modern day forms of communication, and where trusted others are available to manage the overseas operation of the business, there is less of a need for the owner to travel back and forth so often. Thus I would argue that the frequency of travel for business purposes may be a further useful measure of transnational embeddedness but should not be a key defining aspect of a transnational enterprise. The growth in digital transnational businesses which do not involve the physical transfer of resources across national borders also highlights the need for a revised definition of transnationalism.

The framework has identified a means of isolating the transnational inputs and activities of the business and of measuring their geographical spread. In accounting for intangible as well as tangible inputs from multiple nodes of the diaspora, and in viewing transnationalism as continuum, it allows for the greater diversity and fluidity of current day transnational activity amongst ethnic minority entrepreneurs. It is as a result, I would argue, better able to stand the 
test of time than earlier models. The development of a methodology for measuring the relative importance of the different transnational inputs and activities, which will clearly vary across different businesses, would further enhance it. Testing the framework with a larger sample of businesses, from a range of different ethnic groups and business sectors, would also help confirm its validity.

From a policy and business support point of view this study illustrates the importance of understanding the history of migration and the extended transnational networks of the entrepreneur when assessing the resources that the entrepreneur can draw on, and the potential these offer for business innovation, investment, and import and export opportunities. The unique combination of these factors will vary greatly between and within different ethnic groups. In some cases the cross border networks which support transnational activities may be of greater importance than those within the local ethnic economy. However it also needs to be recognised that where these networks do not provide the necessary amount of financial and human capital, and where the nature of the business does not lend itself to transnational inputs, extended levels of social capital obtained transnationally or locally are unlikely to lead to successful business development.

\section{References}

Amelina, A. and Faist, T. (2012) 'De-naturalizing the national in research methodologies: key concepts of transnational studies in migration. Ethnic and Racial Studies, 35(10):170124.

Bagwell, S. (2008) 'Transnational family networks and ethnic minority business development. The case of Vietnamese nail-shops in the UK', International Journal of Entrepreneurial Behaviour and Research, 14 (6): 377-94.

Bagwell, S. (2006) 'UK Vietnamese businesses: cultural Influences and intra-cultural differences’, Environment and Planning C: Government and Policy, 24 (1): 51-69.

Bagwell, S., Hitchcock, M. and Nguyen, K. (2003) Vietnamese Businesses in London. Business Link for London.

Basch, L., Glick Schiller, N. and Szanton-Blanc, C. (1994) 'Nations unbound: transnational projects, postcolonial predicaments, and deterritorialized nation-states’. London: Routledge.

Biernacki, P. and Waldorf, D. (1981) 'Snowball sampling: Problems and techniques of chain referral sampling' Sociological Methods and Research, 10(2): 141-163.

Bourdieu, P. (1986) 'The forms of capital', in Richardson, J. (ed.) The Handbook of Theory and Research for the Sociology of Education, New York, NY Greenwood Press, 24158

Bourdieu, P. (1973) 'Cultural reproduction and social reproduction', in Brown, R. (ed.) Knowledge, education and social change. London: UK Tavistock, 71-112.

Chen, W. and Tan, J. (2009). 'Understanding transnational entrepreneurship through a network lens: Theoretical and methodological considerations', Entrepreneurship Theory and Practice, 33 (5):1079-91.

Chen, W and Wellman, B. (2009) 'NET and JET: The internet use, travel and social networks of Chinese Canadian entrepreneurs'. Information Communication and Society, 12(4):525-547

Coe, N. and Bunnell, T. (2001) 'Spatializing' knowledge communities: towards a conceptualization of transnational innovation networks’, Global Networks, 3 (4): 43756.

Coleman, J. (1988) 'Social capital in the creation of human capital', American Journal of Sociology 94: 595-620. 
Dorais, L. (2001) 'Defining the Overseas Vietnamese', Diaspora, 10(1): 3-27.

Drori, I., Honig, B. and Wright, M. (2009) 'Transnational entrepreneurship: An emergent field of study'. Entrepreneurship Theory and Practice, 33 (5):1001-22

Duke, K. and Marshall, T. (1997) Vietnamese Refugees Since 1992. Research Study 142. Home Office, 50 Queen Anne's Gate, London, SW1H 5HE.

Gowricharn, R. (2008) 'Changing forms of transnationalism.' Ethnic and Racial Studies, 32(9):1619-38.

Hardy, A. (2004) 'Internal transnationalism and the formation of the Vietnamese Diaspora', in: Yeoh and Willis (ed.), State/Nation/Transnation Perspectives on Transnationalism in the Asia-Pacific: 218-37, London: Routledge.

Hüwelmeier, G. (2011) 'Socialist cosmopolitanism meets global Pentecostalism: charismatic Christianity among Vietnamese migrants after the fall of the Berlin Wall. Ethnic and Racial Studies, 34(3): 436-53.

Ip, D. (2007) 'Immigrants from the PRC in Australia', in: Fong, E. and Luk, C. (eds), Chinese Ethnic Business, London: Routledge, 120-31.

IOM (2006) Mapping Exercise Vietnam, International Organisation for Migration, London.

Itzigsohn, J. (1999) 'Mapping Dominican transnationalism: narrow and broad transnational practices', Ethnic and Racial Studies, 2 (2): 316-40.

Jones, T., Ram, M. and Theodorakopoulos, N. (2010) 'Transnationalism as a Force for Ethnic Minority Enterprise? The Case of Somalis in Leicester'. International Journal of Urban and Regional Research, 34 (3): 565-85.

Kariv, D., Menzies T, Brenner, G., and Filion, L.J. (2009) Transnational networking and business performance: Ethnic entrepreneurs in Canada Entrepreneurship and Regional Development 21 (3): 239-64

Kitching, J., Smallbone, D. and Athyde, R. (2009) 'Ethnic Diasporas and Business Competitiveness: Minority-Owned Enterprises in London’, Journal of Ethnic and Migration Studies 35 (4): 689-705.

Landolt, P., Autler, L., and Baires, S. (1999) 'From Hermano Lejano to Hermano Mayor: the dialectics of Salvadoran transnationalism', Ethnic and Racial Studies 22(2):290-315.

Landolt, P. (2001) 'Salvadoran economic transnationalism: Embedded strategies for household maintenance, immigrant incorporation, and entrepreneurial expansion', Global Networks, 1 (3): 21-41.

Levitt, P. (2001) 'Transnational migration: Taking stock and future directions'. Global Networks: a Journal of Transnational Affairs, 1(3): 195-216.

Levitt, P. and Jaworsky, B.N. (2007) 'Transnational migration studies: Past developments and future trends', Annual Review of Sociology 33: 129-56.

McEwan, C., Pollard, J. and Henry, N. (2005) 'The "global” in the city economy: multicultural economic development in Birmingham', International Journal of Urban and Regional Research, 29 (4): 916-33.

Marger, M. (2001) 'The use of social and human capital among Canadian business immigrants' Journal of Ethnic and Migration Studies, 27(3): 439-53.

Miera, F. (2008) 'Transnational strategies of Polish migrant entrepreneurs in trade and small business in Berlin.’ Journal of Ethnic and Migration Studies, 34(5): 753-70.

Morgan, G. (2001) 'Transnational communities and business systems', Global Networks 1(2): 113-30.

Nee, V. and Sanders, J. (2001) 'Understanding the diversity of immigrant incorporation: a forms-of-capital model', Ethnic and Racial Studies, 24 (3):386-411.

Ong, A., and Nonini, D. (Eds.) (1997) Ungrounded Empires: The Cultural Politics of Modern Chinese Transnationalism. New York: Routledge

Portes, A., Guarnizo, L. and Landolt, P. (1999) 'The study of transnationalism: Pitfalls and 
promises of an emergent research field', Ethnic and Racial Studies 22 (2): 217-37.

Portes, A., Haller, W.J. and Guarnizo, L. (2002) 'Transnational Entrepreneurs: An alternative form of immigrant adaptation', American Sociological Review 67 (2): 27898.

Portes, A. (2003) 'Theoretical convergences and empirical evidence in the study of immigrant transnationalism', International Migration Review 37 (3): 814-92.

Ram, M., Theodorakopoulos, N. and Jones, T. (2008) 'Forms of capital, mixed Embeddedness and Somali enterprise’, Work, Employment and Society, 22 (3): 427-46.

Refugee Action (2003) Every tree has its routes. Refugee Action, London

Rusinovic, K. (2008) 'Transnational embeddedness: transnational activities and networks among first and second-generation immigrant entrepreneurs in the Netherlands'. Journal of Ethnic and Migration Studies, 34(3): 431-51.

Sequeira, J, Carr, J. and Rasheed, A. (2009) 'Transnational entrepreneurship: Determinants of firm type and owner attributions of success'. Entrepreneurship Theory and Practice 33(5): 1023-44.

Sims, J. (2007) The Vietnamese Community in Great Britain - Thirty Years On. London: Runnymede Trust.

Sidel, M. (2007) Vietnamese-American Diaspora Philanthropy to Vietnam. Report prepared for The Philanthropic Initiative, Inc and The Global Equity Initiative, Harvard University.

Strauss, A. and Corbin, J. (1990) Basics of Qualitative Research: Grounded Theory Procedures and Techniques, Newbury Park: Sage Publishers.

Thai, T, and Ngoc, H., (2010) 'Microentrepreneurship in a transitional economy: evidence from Vietnam' in in Munoz, J.M. (Ed.), Contemporary Micro-enterprise: Concepts and Cases, Northampton, MA: Edward Elgar Publishing, pp. 32-48.

Vertovec, S. (2004) 'Cheap calls: The social glue of migrant transnationalism', Global Networks, 4 (2): 219-24.

Vertovec, S. (2007) 'Superdiversity and its implications', Ethnic and Racial Studies 30 (6): 1024-54.

Watters, .K. and Biernacki, P. (1989) 'Targeted sampling: Options for the study of hidden populations.' Social Problems 36(4): 416-430.

Wimmer, A. and Glick Schiller, N. (2002) 'Methodological nationalism and beyond: nationstate building, migration and the social science', Global Networks 2 (4): 301-334.

Wong, L. and Ng, M. (2002) 'The emergence of small transnational enterprise in Vancouver: the case of Chinese entrepreneur immigrants', International Journal of Urban and Regional Research, 26 (3): 508-30. 